\title{
PROTECTIONIST THREATS AND FOREIGN DIRECT INVESTMENT
}

\author{
Bruce A. Blonigen \\ Robert C. Feenstra
}

Working Paper 5475

\author{
NATIONAL BUREAU OF ECONOMIC RESEARCH \\ 1050 Massachusetts Avenue \\ Cambridge, MA 02138 \\ March 1996
}

The authors thank David Figlio, Michael Gallaway, Peter Lindert, Deborah Swenson, and participants of the NBER conference, Effects of U.S. Trade Protection and Promotion Policies, Richmond, VA, held October 6-7, 1995 for helpful comments. All errors or omissions are the responsibility of the authors. This paper is part of NBER's research program in International Trade and Investment. Any opinions expressed are those of the authors and not those of the National Bureau of Economic Research.

(c) 1996 by Bruce A. Blonigen and Robert C. Feenstra. All rights reserved. Short sections of text, not to exceed two paragraphs, may be quoted without explicit permission provided that full credit, including $\odot$ notice, is given to the source. 


\title{
PROTECTIONIST THREATS AND
}

FOREIGN DIRECT INVESTMENT

\begin{abstract}
The recent literature on quid pro quo foreign direct investment (FDI) suggests that FDI may be induced by the threat of protection, and further, that FDI may be used as an instrument to defuse a protectionist threat. This paper uses a panel data set of 4-digit SIC level observations of Japanese manufacturing FDI into the United States in the 1980s to explore these hypotheses empirically. We find strong statistical support for the hypothesis that higher threats of protection lead to greater FDI flows, and post-regression simulations find that a rise in the expected probability of protection from five to ten percent means over a 30 percent rise in next-period FDI flows for an average industry. In addition, there is evidence that non-acquisition FDI by the Japanese had success in defusing the threat of an escape clause investigation in future periods.
\end{abstract}

Bruce A. Blonigen

Department of Economics 1285 University of Oregon

Eugene, OR 97403-1285
Robert C. Feenstra

Department of Economics

University of California

Davis, CA 95616

and NBER 


\section{INTRODUCTION}

Avoiding protectionist measures by establishing production facilities in the protectionist country is one of the oldest explanations for foreign direct investment (FDI). Recent papers have added a new extension to this traditional "tariff-jumping" explanation to analyze the possibility that the threat of protection may induce FDI. One explanation is that as the probability of protection rises, foreign firms may engage in more FDI, ceteris paribus, to establish a presence in the host country as an insurance policy in case protectionist barriers arise. This anticipatory tariff-jumping may be especially important, since there may be a substantial lag in establishing a plant in the host country and a firm may lose substantial market share if it does not have a plant in the host country when protectionism is put into place. The majority of papers on protection-induced FDI however, have hypothesized that foreign firms (and/or governments) use FDI as a quid pro quo for a lower future threat of protection.

The concept of quid pro quo FDI was first introduced by Bhagwati (1985) and was more formally detailed and refined in subsequent papers, including Bhagwati et al. (1987), Dinopoulos (1989), Wong (1989), Dinopoulos and Wong (1991), Dinopoulos (1992), and Bhagwati et al. (1992). Grossman and Helpman (1994) is the most recent and fully-specified analysis of this idea. In short, the quid pro quo hypothesis is that a firm may decide to invest in a foreign country (even at a loss potentially) to reduce the "threat" of protection in future periods to keep its export markets open. There have been a number of instances in which it is quite clear that the Japanese have offered FDI as a quid pro quo to avert U.S. protectionism. One of the most recent and obvious 
example is the U.S.-Japan deal that averted a trade war in autos and auto parts in June, 1995. When faced with prohibitive tariffs on luxury automobiles, Japanese automakers promised substantial expansions of their auto plants in the United States -- an interesting concession, since the main issue was supposedly access of U.S. firms to the Japanese market. However, there may be reasons to believe that induced FDI is not a general phenomenon. In particular, Dinopoulos (1989) shows that one primary reason quid pro quo FDI may not occur is the existence of a free rider problem. Specifically, if one foreign firm invests in an export market to reduce protectionist pressure, all firms in the industry that export to the same market may benefit. The larger the free rider problem, the less likely quid pro quo FDI, and the problem may preclude the phenomenon from arising. For this reason, testing whether the threat of protection affects FDI flows is important and relevant.

Despite the solid theoretical work in this area, only one other known paper has empirically explored the relationship between FDI and the threat of protection. Azrak and Wynne (1995) test whether the predicted probability that a U.S. antidumping case will reach a final affirmative decision against a Japanese product affects quarterly Japanese manufacturing FDI in the United States. Azrak and Wynne run into a common problem with empirical analysis of FDI: extremely aggregated data. Using 58 observations over 14 years of manufacturing FDI, they find modest support that the probability of protection affects FDI flows.

This paper extends Azrak and Wynne in numerous ways. First, observations of Japanese FDI into the United States across 4-digit Standard Industrial Classification 
(SIC) manufacturing industries from 1981-1988 are used to test a number of hypotheses that arise from the theory of protection-induced FDI. Since antidumping (AD) and escape clause (EC) investigations are often targeted at very specific products, it makes sense to analyze the threat of protection from these sources at a much more disaggregated industrial level. ${ }^{1}$

Unlike previous analysis this paper is careful to separately estimate the effect of tariff-jumping of actual protection as distinguished from FDI that is induced by the threat of protection. Separate estimates of these two different types of FDI is important for two reasons. First, induced FDI has potentially different welfare implications than tariff-jumping actual protection. Second, there is quite likely a correlation between industries with actual protection in place and those with high predicted probabilities of protection. Estimates using only one of these as an explanatory variable may lead to biased conclusions, since it does not allow separate identification of the two different effects. ${ }^{2}$

Finally, we address whether induced FDI is due to anticipatory tariff-jumping or quid pro quo considerations. Whereas, Wynne and Azrak model FDI as a function of the threat of protection, quid pro quo theory maintains that the threat of protection is

\footnotetext{
' For example, it may be very difficult to discern the effect of an affirmative case on Japanese cyanuric acid imports on manufacturing FDI, than it is to discern the case's effect on cyanuric acid's associated 4-digit SIC industry, Cyclic Orgnaic Crudes and Intermediates.

${ }^{2}$ Azrak and Wynne looked at the effect of the threat of protection in isolation, without modeling the effects of protection in place. By not controlling for actual protection, which is most likely highly correlated with greater probability of protection, it is not clear whether their significant results lend support for induced FDI or tariff-jumping.
} 
a function of lagged FDI as well. Thus we model and test this second connection between FDI and the threat of protection. To further identify when quid pro quo FDI occurs, we note that political motivations behind FDI behavior can be gleaned by the type of FDI a foreign firm engages in and the type of protection foreign firms may be able to defuse with FDI. The type of FDI matters because acquisition FDI may be more likely to create ill will than to defuse protectionist pressure in the host country industry. The type of protection matters because political factors have been shown to influence $\mathrm{EC}$ investigations more than $\mathrm{AD}$ investigations. Thus, quid pro quo influences should be especially strong in non-acquisition FDI flows with respect to escape clause investigations.

Our empirical analysis confirms at the 4-digit SIC level that the threat of protection strongly influences Japanese FDI into the United States. In fact, our estimates find that the threat of protection effect on Japanese FDI flows rivals the effect of actual protection on these flows. In addition, our results suggest that quid pro quo intentions play a major role in this response of FDI to the threat of protection. First, the threat of protection substantially increases non-acquisition FDI, the type of FDI that would be appropriate to defuse a protectionist threat, but has little effect on acquisition FDI. Second, non-acquisition FDI has a stronger response to the threat of EC protection, than $\mathrm{AD}$ protection. Again, this suggests that threat-responding FDI is politically motivated, since EC investigations are more likely to be responsive to political appeasement. Finally, our estimates are able to determine when FDI is successful in defusing future periods' threat of protection. Not surprisingly, the 
strongest evidence for successful quid pro quo FDI is when firms use non-acquisition FDI to defuse the threat of EC protection.

The paper is organized in four sections. The next section briefly reviews the literature on quid pro quo FDI and presents testable hypotheses of the relationship between the threat of protection and FDI. The second section presents the econometric model and data used to test the hypotheses presented in section one. The third section gives results and a final section concludes.

\section{THE EFFECT OF A PROTECTIONIST THREAT ON FDI}

The quid pro quo FDI hypothesis rests on the assumption that foreign firms and/or governments believe they can use FDI to defuse the threat of protection in future periods by appeasing special interest groups in the potentially protectionist country. Bhagwati, et al, 1992, indicate a number of different ways in which FDI may reduce the probability of protection. On the one hand it may be directed at gaining the good will of the host country's government, which represents the "supply of protection." Presumably, the products manufactured by foreign firms will be more palatable to the host government, if they are produced using host country labor. On the other hand, quid pro quo FDI may be intended to placate the groups who are potential "demanders" of protection. These potential demanders include 1) firms, 2) labor unions, and 3) towns/communities in the host country that may be affected by increased import penetration and organized enough to lobby the government for protection. In this respect, Wong (1989) presents a model that specifically models labor union behavior 
and its lobbying efforts for protection, where employment levels of its members is endogenously determined by import protection and FDI.

Sometimes it may be difficult to identify which groups quid pro quo FDI is intended to appease. For example, Japanese auto firms geographically located U.S. production in areas which did not have unionized auto workers. Thus, in this instance, appeasement of labor must not have been a goal of these Japanese firms. There is the additional question of whether FDI is quid pro quo to the specific industry or a more broad appeal to the host government, regardless of the specific industry's view of the FDI. This depends on how large of a role a specific industry can play in host government protection. Given U.S. protectionist laws, where industries petition for relief in a formal process, one would guess that appeasement of the industry (if not its industry groups) would be a primary goal of the quid pro quo FDI. In summary, quid pro quo FDI implies the following general relationship between FDI flows and the threat of protection

$$
\text { Threat }_{t-1} \rightarrow \text { FDI }_{t} \rightarrow \text { Threat }_{t+1}
$$

which leads to the following testable hypotheses:

HYPOTHESIS 1: FDI flows from a foreign country are positively affected by the perceived threat of protection to its export markets in the host country $\left(\right.$ THREAT $_{\text {t-1 }} \rightarrow$ FDI $_{\text {) }}$

HYPOTHESIS 2: FDI defuses the future probability of protection - (FDI THREAT $_{1+1}$ ) 
We decompose the quid pro quo theory into these two hypotheses for the following reason. First, it highlights that there is an inherent lag to the process. This represented lag structure is not an artificial construct, but empirically important. The threat of protection variable is lagged one period from FDI in hypothesis one, since it is assumed that it takes a period for a foreign firm to change its level of FDI in response to changes in the threat of protection. Given the significant lag in establishing new or additional FDI, this is appropriate even if the length of one period is a year. Furthermore, it will take time for FDI to appease special interest groups lobbying for protection in an industry and defuse the threat (hypothesis two). In other words, it may take time for the foreign firms to become involved in the host country industry and be able to influence its political machinery. ${ }^{3}$

A second reason for two separate hypotheses is that whereas hypothesis one is compatible with either quid pro quo FDI or anticipatory tariff-jumping, hypothesis two allows a separate test for quid pro quo intentions only. When increased FDI is observed in response to a rising protectionist threat in the host country (hypothesis one), is it because the foreign firm(s) believe they can defuse the protectionist threat and continue exporting in future periods, or is it because they anticipate future protection and want to get established in the host country by the time that the protection is in place? The former is quid pro quo FDI, the latter is anticipatory tariff-jumping. Anticipatory tariff-jumping may be important, since there may be a substantial lag in

\footnotetext{
${ }^{3}$ In addition, we found little correlation between current FDI and the threat of protection in our data, but significant results with lagged FDI.
} 
establishing a plant in the host country and a firm may lose substantial market share if it does not have a plant in the host country before protectionism is in place.

Disentangling which intention motivates the foreign firm to engage in FDI in the face of rising protectionism is difficult, and the firm may be motivated by both. ${ }^{4}$

One drawback of testing hypothesis two is that it can determine whether quid pro quo FDI is occurring only if quid pro quo FDI is successful. Specifically, FDI may be offered with quid pro quo intentions, but may be unsuccessful in attaining a lower threat of protection. Thus, failure to find a negative correlation between the threat of protection and lagged FDI does not necessarily mean that FDI is not motivated by the desire to reduce the threat of protection, but simply that it may have failed. To better explore if there are political motivations behind FDI flows, we can look at what types of protectionism Japanese FDI responds to. Azrak and Wynne (1995) use AD decisions as an indicator variable to estimate the probability of protection. This paper includes both $\mathrm{AD}$ and $\mathrm{EC}$ affirmative decisions as indicators. However, $\mathrm{AD}$ and $\mathrm{EC}$ investigations often lead to different forms of actual protection and thus have potentially varying consequences. In particular, Finger et al. (1982) describe AD investigations as following a "technical track," whereas EC investigations follow a "political track."

\footnotetext{
${ }^{4}$ Dinopoulos and Wong (1991) make a different distinction between forms of FDI that occur previous to protectionism than the one made here. They distinguish between "protectionist-threatresponding" FDI and quid pro quo FDI. They define "protectionist-threat-responding" protection as FDI by foreign firms when they are "reacting to protectionist threat in a Nash fashion," and quid pro quo FDI when they "defuse the protectionist threat as a Stackelberg leader." We find this distinction unintuitive, since in both cases the foreign firm is investing to lower the threat of protection. Other papers of quid pro quo FDI implicitly refer to both of these types of FDI as quid pro quo.
} 
They find that whether an EC investigation will reach an affirmative decision and lead to actual protection depends on political factors, such as industry structure and its ability to lobby for protection. In contrast, the final decision in an AD case depends on technical facts that are used in the case to determine if their exists a difference between the foreign firm's home price and its export price (i.e., dumping) and if the domestic industry has been injured. It is important to note that the President of the United States has the final decision on whether to enact protectionism in the case of an affirmative EC investigation, whereas affirmative AD cases lead automatically to duties. ${ }^{5}$ As described above, quid pro quo FDI is specifically intended to affect the political process of protectionism. This suggests a third hypothesis

HYPOTHESIS 3: Quid pro quo FDI is more likely in the case of EC investigations than in AD ones.

Testing of hypothesis three will allow a distinction between anticipatory tariff-jumping and quid pro quo. Specifically, with anticipatory tariff-jumping it is expected that the response of FDI flows with respect to higher probabilities of $\mathrm{EC}$ and $\mathrm{AD}$ protectionism are similar, whereas a relatively larger response toward the threat of EC protectionism is expected if FDI is affected by quid pro quo considerations.

\footnotetext{
${ }^{5}$ Duties from an affirmative AD decision may not be imposed if the petitioning industry withdraws or suspends its petition. This may occur in the case where the petitioning industry and foreign firms have made an alternative bargain. For example, AD cases in computer chips from Japan in 1985 were suspended in lieu of the semiconductor agreement between the two countries.
} 
Analysis of the type of FDI foreign firms choose to engage in may also provide information on the firms' political motivations. Bhagwati et al. (1992) note that political perceptions involved with quid pro quo FDI can be very sensitive. For example, they admit that increased Japanese FDI into the U.S, may eventually create "ill will rather than goodwill" if it comes to be perceived as a threat, like import penetration. Despite this, no one has commented on whether various forms of FDI may be more likely to appease special interest groups, and thus are more appropriate for quid pro quo FDI. These considerations will help distinguish between quid pro quo and anticipatory tariff-jumping.

Politically, it is reasonable to expect that quid pro quo FDI would occur through new plants (or "greenfield" FDI), plant expansions, or joint ventures ${ }^{6}$, rather than acquisitions for the following reasons. First, not all acquisitions are "friendly," which may increase the threat of protectionism rather than reduce it. But even those acquisitions that are "friendly" may cause hostility with the target firm's labor and/or community, though they may be acceptable to the target firm's management. These former groups are typically not a significant part of the acquisition agreement. Thus, they may be hostile to the change in ownership and the adjustment process it implies, a process which may be even more difficult because of cultural differences with new foreign owners. Therefore, of the three lobby groups that are part of potential demanders for protectionism, acquisition FDI may appease only one group (firm's

\footnotetext{
6 The discussion below focuses only on the political difference between acquisitions and new plants or plant expansion. Joint ventures seem to be an obvious way to try to appease host country firms in the same industry, as pointed out by Bhagwati et al. (1992).
} 
decision-makers) and aggravate the other two (labor and community). However, these considerations may be mitigated if the target company was on the brink of closing and all groups connected with the target firm are aware of that reality.

In addition, the acquisition may increase protectionist sentiments from other firms in the industry, who may appeal to government to prevent foreign firms from "buying up" their industry. This clearly was the case with the proposed merger of Fujitsu's semiconductor business and Fairchild Semiconductor Corporation in 1986. One industry analyst is quoted as saying in the Wall Street Journal at the time:

“ 'Right now protectionist sentiments are mixed, and I don't think this merger in itself will result in sanctions or opposition by the U.S. government. But when you have one of the best high tech semiconductor companies in the business sell to the Japanese, it's got to raise some eyebrows. And if it's the beginning of a trend of Japanese snapping up weakened U.S. companies, the government might have to respond.' " (WSJ, 10/27/86, p. 6)

A second contrast between acquisition and greenfield investment is related to the timing of job creation in the host country. The immediate impact of a new plant or plant expansion is the creation of new jobs, and all the publicity that goes with the initial hiring process. The long run effect of greenfield investment may mean no new jobs or even lost jobs in the overall economy if the new foreign plant leads to job displacement elsewhere in the industry. But uncertain future losses, potentially dispersed in small amounts across many firms and communities, may have little political weight in the face of the initial large job creation. Acquisitions have no such immediate positive impact. In fact, acquisitions can often bring reorganizations and accompanying immediate job losses. Again, the exception is a target company that is 
known to be on the brink of closure. In this instance there may be an opportunity for the foreign company to play the role of the white knight and "save jobs."

In contrast to quid pro quo FDI, an argument can be made that anticipatory tariff-jumping is more likely to take the form of acquisition FDI. Anticipatory tariffjumping implies that it is important for the firm to establish a presence in the market before protection is in place. However, some forms of FDI, especially construction of a new plant (or greenfield), may take a year or longer to complete. Others have noted that the quickest form of FDI is most likely an acquisition. Thus, with anticipatory tariff-jumping, where time is apparently crucial, one would expect to see acquisition

FDI. This discussion leads to a fourth testable hypothesis:

HYPOTHESIS 4: Quid pro quo FDI is more likely to take the form of greenfield FDI, while anticipatory tariff-jumping is more likely to involve acquisition FDI.

\section{EMPIRICAL MODEL AND DATA}

To formally test hypotheses 1-4, we focus on Japanese FDI into the United States and the role of protectionist pressure in explaining those patterns across manufacturing industries over time. Proponents of quid pro quo FDI have pinpointed Japanese investment patterns in the United States as a likely area for observing the phenomenon. Bhagwati et al. (1992) explicitly state

"there is certainly some plausible, more-than-anecdotal evidence that the acceleration in Japanese DFI in the United States in the early 1980's was due to a mix of 'political' reasons: some partly in anticipation of the imposition of protection, and others partly to defuse its threat." (p. 189) 
As they report, a survey by the Japanese Ministry of International Trade and Investment (MITI) of Japanese firms undertaking foreign investment between 1980 and 1986 found that many were motivated by 'avoiding trade friction.' This is not surprising, since trade groups in Japan publicly encouraged Japanese firms to invest to lower the threat of protection in the United States during this time. For example a 1984 New York Times article reported that

"fearful of trade friction, the Communications Industry Association of Japan, a trade group, has cautioned its members to avoid explosive increases in exports and to build factories in the United States, according to Haruo Ozawa, its president." (New York Times, 5/2/84)

Japanese industrial structure may make observation of quid pro quo FDI more likely as well. The Japanese Ministry of International Trade and Industry (MITI) and keiretsu industrial linkages have been cited often as elements in the Japanese economy that may allow a greater degree of industrial collusion than in other developed countries. We will test for the importance of keiretsu relations in the FDI decision below. By facilitating coordination of FDI and export flows, the unique Japanese institutional and industrial structures may lessen any potential free-rider problem inherent in an industry faced with protectionist threat in its export markets.

\section{Econometric Model}

Testing the relationship between FDI and the threat of protection is difficult precisely because it is impossible to measure or observe the threat of protection directly. However, the formal institutional process in the United States that 
accompanies $\mathrm{EC}$ and $\mathrm{AD}$ protection provides perhaps the best indication of when protectionist pressures in a U.S, industry are high. As successive GATT rounds have reduced Most Favored Nation tariff rates and longstanding quota arrangements, EC and $\mathrm{AD}$ law are the main ways that new protectionism has occurred in the United States in the past decades. AD and EC investigations also focus on very specific products and industries, which makes the threat of protection industry specific, and thus more easily identified. Thus, an indication of the threat of protection is whether imports in an industry become subject to an affirmative EC or $\mathrm{AD}$ decision. ${ }^{7}$ We can use this indicator variable to model the relationship between the underlying latent variable and explanatory variables by assuming that

$$
\begin{aligned}
Z_{i, t-1}^{*}=W_{i, t-1} \gamma+\eta_{i, t-1}, \text { where } Z_{i, t-1} & =1 \text { if } Z_{i t}^{*}>0, \\
Z_{i, t-1} & =0 \text { if } Z_{i i}^{*}<0
\end{aligned}
$$

and where $Z_{i, t-1}^{*}$ is the threat of protection in industry $i$ and year $t-1, Z_{i, t-1}$ is the indicator variable of whether an affirmative $\mathrm{AD}$ or $\mathrm{EC}$ decision is made, $\mathrm{W}_{\mathrm{i}, \mathrm{t}-\mathrm{l}}$ are explanatory variables that represent industrial, political, and overall U.S. economic factors that influence the threat of protection, $\gamma$ is the parameter vector, and $\eta_{i, t-1}$ is the

\footnotetext{
' Section 301 trade actions, which are neatly analyzed in Bayard and Elliott (1994), were also considered as possible indications of protectionist threat. However, the majority of 301 activity with respect to Japan has targeted market access of U.S. firms in Japan with respect to products that Japan does not import to the United States (specifically, tobacco and citrus fruit products) Other 301 actions with respect to Japan occurred simultaneously with an AD or EC investigation of the same subject product. Thus, it would be impossible to separate out the effect of the 301 action from the $\mathrm{AD}$ or $\mathrm{EC}$ action we model.
} 
error term assumed to be $\mathrm{N}(0,1){ }^{8}$ Appropriate estimation of this model can be done with a standard probit model. A number of studies have analyzed a similar model to help predict which industries will have successful $A D$ or $E C$ investigations brought against U.S. imports, including Takacs (1981), Salvatore (1987), and Coughlin et al. (1989). Unlike past studies, we use the model to determine whether previous FDI lowers the threat of protection (hypothesis two), by including lagged FDI as an explanatory variable in $W_{i, t-1}$.

The unobservable nature of the threat of protection also affects estimation of whether the threat of protection affects FDI (hypothesis one). To test hypothesis one, assume Japanese FDI in industry $i$ in year $t$ is specified as

$$
Y_{i t}=X_{i t} \beta+Z_{i, t-1}^{*} \delta+\epsilon_{i t}
$$

where $Y_{i t}$ is ( $\left.n \times 1\right)$ vector of Japanese FDI, $X_{i l}$ is a ( $n \times k$ ) vector of $k$ explanatory variables besides the threat of protection variable, $\beta$ is a $(\mathbf{k} \times 1)$ vector of coefficients, $Z_{i, k-1}$ represents the threat of protection last period, $\delta$ is its associated coefficient, $\epsilon_{i t}$ is an $(\mathrm{n} \times 1)$ error term, and $\mathrm{n}=\mathrm{i} \times \mathrm{t}$. Once again, the variable, $\mathrm{Z}_{\mathrm{i}, \mathrm{t}-1}^{*}$ has an asterisk associated with it because we cannot observe this variable, rather we observe $Z_{i, t-1}$. Whereas the latent variable is the dependent variable in equation (2), the latent variable is in the explanatory variables of equation (3) and estimates using the observable

\footnotetext{
"The variables in equation (2) are written as lagged variables with subscript ( $t-1)$ since this equation will generate predicted probabilities of protection to explain next period FDI, as predicted by theory and modeled in equation (4) below.
} 
indicator variable as a proxy need not be consistent. ${ }^{9}$ However, whether the latent variable is observable to the agents being modeled is important for testing. In this case, the unobservable variable (the threat of protection) is not only unknown to the researcher, but also most likely unknown to the agents being modeled, the foreign firms making FDI decisions. Thus, assuming that foreign firms use the same information set as available to us ( $W_{i f}$ in equation (2)), the predicted (i.e., expected) probability of protection from equation $(2), t-1, \hat{z}_{i,-1}$, not the unobservable threat of protection, $Z_{i, t-1}^{*}$, is the appropriate regressor. Thus, hypothesis one is tested with

$$
Y_{i t}=X_{i t} \beta+\hat{Z}_{i, t-1} \delta+\epsilon_{i t}
$$

In summary, from estimating equation (2) we obtain estimated predicted probabilities of filings for all industries $\mathrm{i}$ across all years $\mathrm{t}-\mathrm{l}, \hat{z}_{\mathrm{i}, t-1}$. Assuming the error terms of the two equations are independent, this predicted probability, $\hat{Z}_{i, t-1}$ can be substituted in (4) to obtain consistent maximum likelihood estimates. ${ }^{10,11}$

\footnotetext{
9 See Goldberger (1972) and Pagan (1984).

10 See Maddala (1983), pp. 117-123.
}

11 This situation can be contrasted with the case where a variable is unobservable to the researcher, but known to the agents in the process being modeled. This is the classic case of latent variable estimation, where simply inserting the predictions from equation (3) for $Z_{i, t-1}^{*}$ in equation (2) will lead to inconsistent standard errors in the linear setting, and has unknown properties in the nonlinear setting used in this paper - see Goldberger (1972) and Pagan (1984). Because it is likely that foreign firms are removed from actual observation of the U.S. protectionist threat, the assumption used here does not seem restrictive and makes estimation more tractable. 
Assuming that the error terms are independent is consistent with the relation between the threat of protection and FDI shown in equation (1), whereby FDI levels and the threat of protection are not contemporaneously (i.e., simultaneously) determined. Current values of each variable are affected by lagged, predetermined values of the other. Provided that the threat of protection and FDI are not correlated with their own past values two periods before, the two equations' error terms are independent. Because it is more likely that noncontemporaneous correlation exists with FDI, we correct for this in equation (4) as described below. As mentioned, equation (2) by itself has been the subject of empirical investigation, as a number of papers have modeled the probability that a U.S. industry will file an AD and/or an EC petition, including Takacs (1981), Herander and Schwartz (1984), Salvatore (1987), Coughlin et al. (1989), Moore (1992), Baldwin and Steagall (1994), Azrak and Wynne (1995), and Hansen and Prusa (forthcoming). Relying primarily on these studies and hypothesis two, we include the following as explanatory variables in estimating equation (2):

1) Previous period real Japanese import growth in industry.

2) Previous period real domestic shipment growth of U.S. industry.

3) Share of Japanese imports in industry i of total Japanese imports in U.S.

4) Share of Japanese imports in industry $i$ to total imports in industry $i$.

5) Union presence in U.S. industry $i$.

6) Industry wage to value added.

7) Previous period AD/CVD investigations of other countries' imports in industry i.

8) Real U.S. GNP growth.

9) Lagged FDI.

Variables 1, 3, and 4 capture how prominent Japanese import penetration has been in the industry in absolute terms, relative to total Japanese imports in the United States, and relative to other country's imports in the industry. The more prominent the 
Japanese import penetration, the more likely a petition is filed by the U.S. domestic industry for relief. Variable 2 is intended to capture how well the U.S. industry is performing, since an injury test in $\mathrm{AD}$ investigations is a statutory requirement for affirmative determinations. Lower real shipment growth should raise the probability of an affirmative decision. Variables 5 and 6 are intended to assess how prominent and powerful U.S. labor interests are in an industry, since, as Bhagwati et al. (1992) point out, labor groups can be a strong and important lobby group for protectionist pressure. Thus, a larger labor presence should increase the likelihood of an affirmative AD or EC petition.

Justification for including variable 7 and expecting a positive correlation is that once an industry has employed substantial fixed costs for filing an initial case and acquiring institutional knowledge of U.S. protectionist law, the marginal cost in future periods of filing for relief is much lower. Trade diversion from previous cases may also play an important role. When a number of foreign countries' imports of a certain product suffer AD or CVD duties, this competition barrier can benefit not only the U.S. industry, but also the foreign importers that did not come under investigation. Thus, these nonsubject imports can often increase substantially, raising the probability that they come under future investigations. Finally, variable 8 relates to economywide factors that may influence the likelihood of filings across years and variable 9 test hypothesis two.

The theory of FDI suggests a number of explanatory variables for equation (4) - in addition to the threat variable - that have performed well in previous empirical 
analyses. As discussed in the data section below, we use a panel data set of Japanese

FDI in the United States across 4-digit SIC manufacturing industries and the years

1981-88. Thus, the specified explanatory variables address both the cross-section and time-series dimensions of the dependent variable, Japanese FDI into the United States. ${ }^{12}$

One of the more prominent theories of FDI is internalization. Internalization, which arose out of the transactions cost literature, postulates that firms with more firmspecific assets are more likely to engage in FDI. For these firms, external market transactions with another party, such as exporting or licensing, may not adequately take advantage of firm-specific assets, as would be the case if the transactions were internalized (i.e., setting up one's own operations in the foreign country). ${ }^{13}$ To proxy Japanese industries which enjoy larger stocks of these firm-specific assets, we use R\&D expenditures by industry and expect a positive coefficient. R\&D expenditures have been used by a number of other empirical studies similarly and show significant explanatory power. ${ }^{14}$

Exchange rate changes have shown explanatory power in a number of empirical studies (See Swenson (1994), Ray (1991), Froot and Stein (1991)), Azrak and

\footnotetext{
12 Many empirical studies of FDI either explore theories that explain cross-sectional variation of FDI patterns (eg., Kogut and Chang (1991)) or theories that explain variations in aggregate FDI across years. (eg., Froot and Stein (1991) and Martin (1991)). For studies that use panel data see Ray (1991) and Blonigen (1995).

${ }^{13}$ For example, licensing another firm in a foreign country involve "transactions" costs if your firm has superior marketing abilities.

${ }^{14}$ These studies include Martin (1991) and Grubaugh (1987).
} 
Wynne (1995) and Blonigen (1995). Both Froot and Stein (1991) and Blonigen (1995) present theoretical models that predict dollar depreciations relative to the yen increase Japanese FDI into the United States. Thus, the yen-dollar exchange rate is included with an expected negative sign.

Other studies examining foreign countries investment patterns in the United States over time have included real GNP growth in the foreign country as an explanatory variable. ${ }^{15}$ One would expect higher growth rates of overall economic activity to be positively correlated with a country's investment both within the foreign country and its investment abroad. Thus, we include Japanese real GNP growth and expect a positive sign. ${ }^{16}$

We also include a variable specific to Japanese economic behavior: keiretsu relationships. Lawrence (1991 and 1993) detail important ways in which keiretsu relationships may influence Japanese economic activity and show empirically that it has a substantial impact on the level of imports and inward FDI in Japan. The large horizontal keiretsus of Japan are centered around the Japanese economy's largest banks. One way firms affiliated with a keiretsu may be different with respect to their outward FDI behavior is perhaps through their easier access and lower cost of external financing because of these keiretsu linkages to a major bank. In addition, Dinopoulos (1989) showed that market structure considerations may affect the phenomenon of quid pro quo

19 See Ray (1991) and Martin (1991).

${ }^{16}$ Martin (1991) found this variable to be statistically significant in explaining Japanese investment in the U.S. 
FDI, as discussed above. Thus, we include the degree of keiretsu linkages across a Japanese industry and expect a positive sign.

One of the oldest explanations for FDI is the avoidance of protection which is in place; i.e. tariff-jumping. Once protectionist barriers are erected to foreign imports, foreign firms invest in the protectionist country to get behind the tariff wall. Thus, we include a protection variable to indicate the presence of EC or negotiated trade agreements with Japan or AD duties in place in an industry on Japanese products. We assume that relative levels of protection from other sources in the U.S. economy (i.e., Most Favored Nation tariff rates and longstanding quotas) remain unchanged over our sample, and thus have no effect on changes in FDI flows over our sample.

\section{Data}

To test the model, we must necessarily rely on numerous data sources, each with potential limitations in coverage and otherwise. The most difficult variable with respect to data is information on Japanese FDI flows into the United States. Credible testing of our model requires both cross-sectional detail and a time-series dimension as explained above. Thus, we rely on a yearly publication by the International Trade Administration (ITA) at the Department of Commerce (DOC), Foreign Direct Investment in the United States. The appendix of this publication contains a compiled list of FDI transactions reported in public sources during the year, including the type of 
investment ${ }^{17}$, the foreign investor and country, the 4-digit SIC of the U.S. investment ${ }^{18}$, the state it's located in, and the dollar value of the transaction. The disaggregate nature of the ITA data (specifying individual observations of FDI by type, country, and 4-digit SIC industry) distinguish it from the data published annually by the Bureau of Economic Analysis (BEA) in the Survey of Current Business, which reports more aggregate statistics. However, BEA relies on private survey data, whereas ITA records FDI from publicly available sources. Figure 1 graphs two comparable aggregate measures of

Figure 1: Measures of Japanese Manufacturing FDI Activity in the U.S.

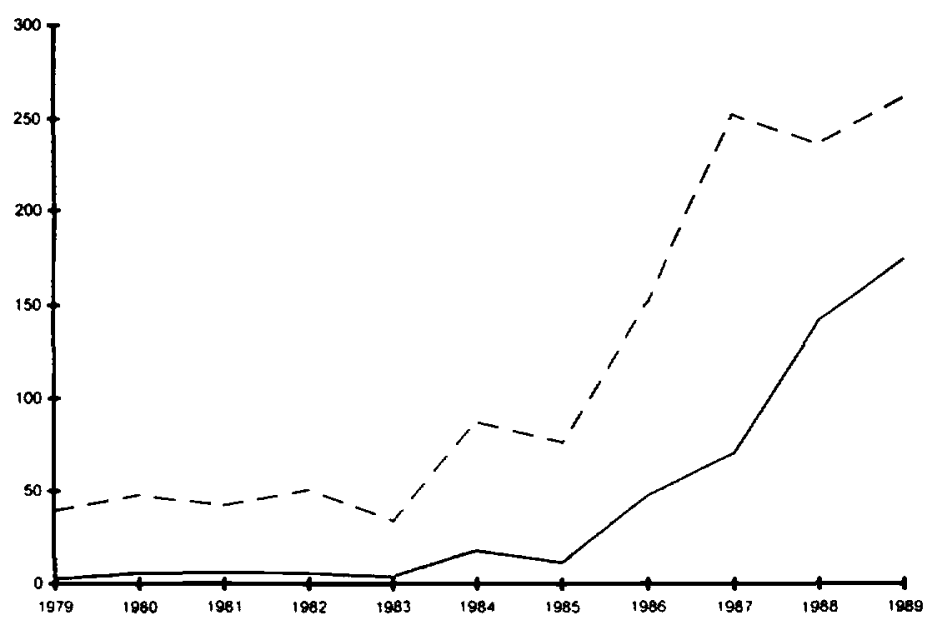

- Dollar value of investment outlays in Counts of FDI occurrences (ITA) hundreds of thousands (BEA)

Source: BEA data is taken from the Survey of Current Business, various issues, and ITA data is from the appendix of the annual ITA publication, Foreign Investment in the United States

17 The different types of FDI it separately identifies are acquisitions and mergers, new plants, joint ventures, plant expansions, reinvested earnings, equity increases, and other.

${ }^{18}$ With acquisitions, this means the 4-digit SIC classification of the target firm. 
Japanese FDI activity from 1979-1989, with one line representing the number of Japanese manufacturing FDI occurrences in the U.S. reported by ITA, whereas the other represents a BEA measure of Japanese outlays for acquisitions and new establishments in the U.S. It is easy to see that the two series follow each other closely (correlation is 0.91 ), suggesting that the ITA consistently matches the private survey data of BEA. In addition, ITA count data patterns for broad manufacturing groups were matched to BEA data with strong, positive correlation coefficients as well. ${ }^{19}$ Dollar values of FDI are not necessarily a matter of public record, thus dollar values for observations are reported by the ITA database only about one-half to twothirds of the time. Thus, we specify our dependent variable in equation (4) as the discrete number of FDI occurrences that occur in a 4-digit industry $i$ in year $t$. To model this dependent variable correctly we employ a discrete probability model, negative binomial, to obtain maximum likelihood estimates. ${ }^{20}$ The panel nature of the data is a concern as well, however, particularly serial correlation problems. If lagged FDI is correlated with current FDI in the sample, estimates need not be consistent. Thus, we assume that each industry $i$ has its own unobservable propensity to engage in FDI, $\theta_{i}$, which is independently and identically distributed across industries.

Conditional on $\theta_{i}$, FDI for a given industry in one period is independent of its FDI in

\footnotetext{
${ }^{19}$ Correlation coefficients between the two series were 0.79 for machinery, 0.73 for chemicals and their allied products, 0.66 for primary and fabricated metals, and 0.70 for other manufacturing.

${ }^{20}$ Kogut and Chang (1991) use the same database and use a negative binomial specification as well.
} 
other periods. ${ }^{21}$ Following Hausman et al. (1984), assume that the ratio $\theta_{\mathrm{i}} /\left(1+\theta_{\mathrm{i}}\right)$ isdistributed as a beta random variable with shape parameters $(a, b)$. Using this beta density, the joint probability of an industry's acquisitions over the panel of years is

$$
\begin{aligned}
\operatorname{pr}\left(Y_{i 1}, \ldots, Y_{i T} \mid X_{i 1}, \ldots, X_{i T}\right) & \\
= & \frac{\Gamma(a+b) \Gamma\left(a+\sum \gamma_{i t}\right) \Gamma\left(b+\sum Y_{i t}\right.}{\Gamma(a) \Gamma(b) \Gamma\left(a+b+\sum \gamma_{i p}+\sum Y_{i p}\right)}\left(\Pi \frac{\Gamma\left(\gamma_{i t}+Y_{i t}\right)}{\Gamma\left(\gamma_{i p}\right) \Gamma\left(Y_{i t}+1\right)}\right)
\end{aligned}
$$

where $\gamma_{i t}=\exp \left(Q_{i t} \pi\right)$ and $Q_{i t}$ and $\pi$ are the combined regressor matrix and associated coefficients, $\left[x_{i,}, \hat{z}_{i, t-1}\right]$ and $[\boldsymbol{\beta} \mid \delta]$ in equation (4). Maximum likelihood techniques estimate $a$ and $b$ in addition to our coefficient vector, $[\beta \mid \delta]$.

Significant changes in the AD law came into place in 1980. In addition, tariff schedules and the Standard Industrial Classification (SIC) system underwent substantial changes in the late 1980 s, creating consistency problems with a number of important variables across this time period. As a result, we limit our sample to the years 198188. Missing observations in some explanatory variables leaves a sample of 299 4-digit manufacturing industries over 8 years. ${ }^{22}$ The history of $A D$ and EC investigations against Japanese products during 1980-87) are listed in table 1, of which the affirmative

${ }^{21}$ This assumption is similar to that used by Staiger and Wolak (1994).

${ }^{22}$ Import data for some of the 4-digit industries were missing and import levels in a few cases jumped from zero to positive levels and back again, making import growth figures noncalculable. In addition, shipment data were missing for a couple of industries. 
Table 1

AD, CVD, and EC Investigations Affecting Japanese Products, 1980-87.

\begin{tabular}{|c|c|c|c|c|}
\hline $\begin{array}{l}\text { Inv. } \\
\text { Type }\end{array}$ & Year & Product & SIC & Decision \\
\hline $\begin{array}{l}\mathrm{AD} \\
\mathrm{AD} \\
\mathrm{EC}\end{array}$ & $\begin{array}{l}1980 \\
1980 \\
1980\end{array}$ & $\begin{array}{l}\text { Pipes/Tubes of Iron and Steel } \\
\text { Menthol } \\
\text { Motor Vehicles }\end{array}$ & $\begin{array}{l}3312 \\
2865 \\
3711\end{array}$ & $\begin{array}{l}\text { Negative } \\
\text { Negative } \\
\text { Negative* }\end{array}$ \\
\hline $\begin{array}{l}\mathrm{AD} \\
\mathrm{AD} \\
\mathrm{AD} \\
\mathrm{EC}\end{array}$ & $\begin{array}{l}1981 \\
1981 \\
1981 \\
1981\end{array}$ & $\begin{array}{l}\text { Steel Wire Nails } \\
\text { Amplifiers } \\
\text { Stainless Steel Clad Plate } \\
\text { Fishing Rods and Parts }\end{array}$ & $\begin{array}{l}3315 \\
3662 \\
3312 \\
3949\end{array}$ & $\begin{array}{l}\text { Terminated } \\
\text { Affirmative } \\
\text { Affirmative } \\
\text { Negative }\end{array}$ \\
\hline $\begin{array}{l}A D \\
A D \\
A D \\
E C \\
E C \\
E C\end{array}$ & $\begin{array}{l}1982 \\
1982 \\
1982 \\
1982 \\
1982 \\
1982\end{array}$ & $\begin{array}{l}\text { Seamless Steel Pipes } \\
\text { High Capacity Pagers } \\
\text { Portland Cement } \\
\text { Tubeless Tire Valves } \\
\text { Heavyweight Motorcycles } \\
\text { Stainless Steel \& Alloy Tool Steel }\end{array}$ & $\begin{array}{l}3312 \\
3662 \\
3241 \\
3714 \\
3751 \\
3312\end{array}$ & $\begin{array}{l}\text { Affirmative } \\
\text { Affirmative } \\
\text { Negative } \\
\text { Negative } \\
\text { Affirmative } \\
\text { Affirmative }\end{array}$ \\
\hline $\mathrm{AD}$ & 1983 & Polyester Fabric & 2221 & Terminated \\
\hline $\begin{array}{l}\text { AD } \\
A D \\
A D \\
A D \\
A D \\
\text { EC }\end{array}$ & $\begin{array}{l}1983 \\
1983 \\
1983 \\
1983 \\
1983 \\
1983\end{array}$ & $\begin{array}{l}\text { Tapered Roller Bearings } \\
\text { Cyanuric Acid } \\
\text { Spindle Belting } \\
\text { Steel Valves } \\
\text { Titanium Sponge } \\
\text { Stainless Steel Table Flatware }\end{array}$ & $\begin{array}{l}3562 \\
2865 \\
2399 \\
3492 \\
3339 \\
3914\end{array}$ & $\begin{array}{l}\text { Negative } \\
\text { Affirmative } \\
\text { Negative } \\
\text { Negative } \\
\text { Affirmative } \\
\text { Negative }\end{array}$ \\
\hline $\begin{array}{l}A D \\
A D \\
A D \\
A D \\
A D \\
A D \\
E C\end{array}$ & $\begin{array}{l}1984 \\
1984 \\
1984 \\
1984 \\
1984 \\
1984 \\
1984\end{array}$ & $\begin{array}{l}\text { Cellsite Transceivers } \\
\text { Eyeglass Lenses } \\
\text { Calcium Hypochlorite } \\
\text { Stainless Steel Wire Cloth } \\
\text { Neoprene Laminate } \\
\text { Cellular Mobile Phones } \\
\text { Nonrubber Footwear }\end{array}$ & $\begin{array}{l}3662 \\
3851 \\
2819 \\
3496 \\
2822 \\
3661 \\
3143 \\
3144 \\
3149\end{array}$ & $\begin{array}{l}\text { Affirmative } \\
\text { Withdrawn } \\
\text { Affirmative } \\
\text { Terminated } \\
\text { Affirmative } \\
\text { Affirmative } \\
\text { Negative } \\
\text { Negative } \\
\text { Negative }\end{array}$ \\
\hline EC & 1984 & Carbon/Specialty Steel Products & $\begin{array}{l}3312 \\
3315 \\
3317\end{array}$ & $\begin{array}{l}\text { Affirmative } \\
\text { Affirmative } \\
\text { Affirmative }\end{array}$ \\
\hline $\begin{array}{l}\mathrm{EC} \\
\mathrm{EC} \\
\mathrm{EC}\end{array}$ & $\begin{array}{l}1984 \\
1984 \\
1984 \\
1984\end{array}$ & $\begin{array}{l}\text { Unwrought Copper } \\
\text { Certain Canned Tuna } \\
\text { Potassium Permanganate } \\
\text { Nonrubber Footwear }\end{array}$ & $\begin{array}{l}3331 \\
2091 \\
2819 \\
3143 \\
3144 \\
3149\end{array}$ & $\begin{array}{l}\text { Affirmative } \\
\text { Negative } \\
\text { Negative } \\
\text { Affirmative } \\
\text { Affirmative } \\
\text { Affirmative }\end{array}$ \\
\hline
\end{tabular}

* Despite negative decision by the U.S. International Trade Commission, the President imposed protection on this product, and thus this observation is treated as an affirmative decision in the statistical analysis. 
Table 1 continued:

AD, CVD, and EC Investigations Affecting Japanese Products, 1980-87.

\begin{tabular}{|c|c|c|c|c|}
\hline $\begin{array}{l}\text { Inv. } \\
\text { Type }\end{array}$ & Year & Product & SIC & Decision \\
\hline $\begin{array}{l}\mathrm{AD} \\
\mathrm{AD}\end{array}$ & $\begin{array}{l}1985 \\
1985\end{array}$ & $\begin{array}{l}\text { Offshore Platform Jackets } \\
\text { Nylon Impression Fabric }\end{array}$ & $\begin{array}{l}3441 \\
2221 \\
2241\end{array}$ & $\begin{array}{l}\text { Affirmative } \\
\text { Terminated } \\
\text { Terminated }\end{array}$ \\
\hline $\begin{array}{l}\text { AD } \\
\text { AD } \\
\text { AD } \\
\text { EC } \\
\text { EC }\end{array}$ & $\begin{array}{l}1985 \\
1985 \\
1985 \\
1985 \\
1985\end{array}$ & $\begin{array}{l}\text { 64K DRAMs } \\
\text { EPROMs } \\
\text { 256K DRAMs } \\
\text { Electric Shavers } \\
\text { Certain Metal Castings }\end{array}$ & $\begin{array}{l}3674 \\
3674 \\
3674 \\
3634 \\
3321 \\
3322 \\
3492 \\
3494 \\
3499 \\
3523 \\
3524 \\
3531 \\
3585 \\
3714 \\
3732\end{array}$ & $\begin{array}{l}\text { Affirmative } \\
\text { Affirmative } \\
\text { Suspended } \\
\text { Negative } \\
\text { Negative } \\
\text { Negative } \\
\text { Negative } \\
\text { Negative } \\
\text { Negative } \\
\text { Negative } \\
\text { Negative } \\
\text { Negative } \\
\text { Negative } \\
\text { Negative } \\
\text { Negative }\end{array}$ \\
\hline $\mathrm{EC}$ & 1985 & Apple Juice & 2037 & Negative \\
\hline $\mathrm{AD}$ & 1986 & Butt-weld Pipe Fittings & $\begin{array}{l}3494 \\
3498\end{array}$ & $\begin{array}{l}\text { Terminated } \\
\text { Terminated }\end{array}$ \\
\hline$A D$ & 1986 & Butt-weld Pipe Fittings & $\begin{array}{l}3494 \\
3498\end{array}$ & $\begin{array}{l}\text { Affirmative } \\
\text { Affirmative }\end{array}$ \\
\hline $\begin{array}{l}\mathrm{AD} \\
\mathrm{AD} \\
\mathrm{AD}\end{array}$ & $\begin{array}{l}1986 \\
1986 \\
1986\end{array}$ & $\begin{array}{l}\text { Clear Glass Mirrors } \\
\text { Tapered Roller Bearings } \\
\text { Malleable Pipe Fittings }\end{array}$ & $\begin{array}{l}3211 \\
3562 \\
3494 \\
3498\end{array}$ & $\begin{array}{l}\text { Negative } \\
\text { Affirmative } \\
\text { Affirmative } \\
\text { Affirmative }\end{array}$ \\
\hline $\begin{array}{l}\mathrm{AD} \\
\mathrm{AD} \\
\mathrm{AD} \\
\mathrm{AD} \\
\mathrm{EC} \\
\mathrm{EC}\end{array}$ & $\begin{array}{l}1986 \\
1986 \\
1986 \\
1986 \\
1986 \\
1986\end{array}$ & $\begin{array}{l}\text { Forged Steel Crankshafts } \\
\text { Silica Filament Fabric } \\
\text { Portland Cement } \\
\text { Color Picture Tubes } \\
\text { Wood Shingles and Shakes } \\
\text { Steel Fork Arms }\end{array}$ & $\begin{array}{l}3566 \\
2221 \\
3241 \\
3671 \\
2499 \\
3537\end{array}$ & $\begin{array}{l}\text { Negative } \\
\text { Affirmative } \\
\text { Negative } \\
\text { Affirmative } \\
\text { Affirmative } \\
\text { Negative }\end{array}$ \\
\hline $\begin{array}{l}\mathrm{AD} \\
\mathrm{AD}\end{array}$ & $\begin{array}{l}1987 \\
1987\end{array}$ & $\begin{array}{l}\text { Copier Toner } \\
\text { Butt-weld Pipe Fittings }\end{array}$ & $\begin{array}{l}2865 \\
3494 \\
3498\end{array}$ & $\begin{array}{l}\text { Negative } \\
\text { Affirmative } \\
\text { Affirmative }\end{array}$ \\
\hline $\begin{array}{l}A D \\
A D \\
A D \\
A D \\
A D\end{array}$ & $\begin{array}{l}1987 \\
1987 \\
1987 \\
1987 \\
1987\end{array}$ & $\begin{array}{l}\text { Forklift Trucks } \\
\text { Brass Sheet and Strip } \\
\text { Bimetallic Cylinders } \\
\text { Nitrile Rubber } \\
\text { Granular PTFE Resin }\end{array}$ & $\begin{array}{l}3537 \\
3351 \\
3559 \\
2822 \\
2821\end{array}$ & $\begin{array}{l}\text { Affirmative } \\
\text { Affirmative } \\
\text { Negative } \\
\text { Affirmative } \\
\text { Affirmative }\end{array}$ \\
\hline
\end{tabular}

Source: U.S. International Trade Commission (USITC) annual reports and concordances maintained at the USITC. 
decisions are used as an indicator of the threat of protection. ${ }^{23}$ A data appendix discusses sources for the other variables used in the analysis.

\section{RESULTS}

Our analysis begins with testing equation (2) and the hypothesis that lagged FDI affects the threat of protection. The predicted probabilities are then used in estimating equation (4) and testing the hypothesis that FDI is affected by previous period threat of protection. After initial estimates, we test the effect of different forms of possible new protection (hypothesis three) and different forms of FDI (hypothesis four) on the estimated relationships. As discussed above, testing of equation (2) provides evidence of whether FDI is successful in defusing the threat of protection, while equation (4) tests if and to what extent the threat of protection motivates firms to engage in FDI.

Column 1 of table 2 presents initial maximum likelihood probit estimates of the probability of an AD or EC filing in industry $i$ in year $t-1$. Overall, the equation shows a good fit, as the likelihood ratio test easily rejects the null hypothesis that the coefficients of the equation are jointly zero. In addition, most of the explanatory variables have their expected sign. In particular, Japanese import growth and penetration variables are all positively related to a higher probability of protectionism in an industry. Previous period investigations of other country's imports in the industry is highly significant as well, suggesting that once the U.S. industry has incurred the fixed

\footnotetext{
${ }^{23}$ Data used for these cases are from 1980-1987, not 1981-1988, because the threat of protection equation is lagged one period.
} 
Table 2

Probit Estimates for Predicting Affirmative Decisions on Japanese Products Across 4-Digit SIC Manufacturing Industries, 1980-1987.

\begin{tabular}{|c|c|c|c|}
\hline & $\begin{array}{l}\text { Threat of } \\
\text { Protection }\end{array}$ & $\begin{array}{c}\text { Threat of EC } \\
\text { Protection }\end{array}$ & $\begin{array}{l}\text { Threat of } \mathrm{AD} \\
\text { Protection }\end{array}$ \\
\hline Constant & $\begin{array}{l}-3.170^{* * *} \\
(0.339)\end{array}$ & $\begin{array}{l}-4.899 * * * \\
(0.787)\end{array}$ & $\begin{array}{l}-2.969 * * * \\
(0.373)\end{array}$ \\
\hline Lagged real Japanese import growth & $\begin{array}{l}0.005^{* *} \\
(0.002)\end{array}$ & $\begin{array}{c}0.004^{*} \\
(0.003)\end{array}$ & $\begin{array}{c}-0.012 \\
(0.072)\end{array}$ \\
\hline Lagged real domestic shipments growth & $\begin{array}{c}-0.578 \\
(0.679)\end{array}$ & $\begin{array}{c}-0.636 \\
(1.067)\end{array}$ & $\begin{array}{c}-0.287 \\
(0.797)\end{array}$ \\
\hline Share of Japanese imports to total Japanese imports & $\begin{array}{l}3.485 * \\
(1.782)\end{array}$ & $\begin{array}{l}10.912 * * \\
(5.015)\end{array}$ & $\begin{array}{c}1.159 \\
(2.462)\end{array}$ \\
\hline Share of Japanese imports to total all imports & $\begin{array}{l}0.798^{*} \\
(0.429)\end{array}$ & $\begin{array}{l}-0.469 \\
(0.842)\end{array}$ & $\begin{array}{l}1.201^{* *} \\
(0.496)\end{array}$ \\
\hline Union presence & $\begin{array}{c}0.006 \\
(0.006)\end{array}$ & $\begin{array}{c}0.017^{*} \\
(0.010)\end{array}$ & $\begin{array}{c}0.004 \\
(0.006)\end{array}$ \\
\hline Industry wage to value added ratio & $\begin{array}{c}0.178 \\
(0.938)\end{array}$ & $\begin{array}{l}3.370^{* *} \\
(1.690)\end{array}$ & $\begin{array}{c}-1.105 \\
(1.114)\end{array}$ \\
\hline Past investigations of other countries' imports & $\begin{array}{l}0.911^{* * *} \\
(0.200)\end{array}$ & $\begin{array}{c}0.529 \\
(0.400)\end{array}$ & $\begin{array}{l}1.137^{* * *} \\
(0.212)^{2}\end{array}$ \\
\hline U.S. real GNP growth & $\begin{array}{l}0.091^{* *} \\
(0.038)\end{array}$ & $\begin{array}{l}0.126^{*} \\
(0.066)\end{array}$ & $\begin{array}{c}0.670 \\
(0.435)\end{array}$ \\
\hline FDI lagged 1 & $\begin{array}{c}0.110 \\
(0.078)\end{array}$ & $\begin{array}{l}-0.961 \\
(0.639)\end{array}$ & $\begin{array}{c}0.133^{*} \\
(0.080)\end{array}$ \\
\hline FDI lagged 2 & $\begin{array}{c}0.008 \\
(0.103)\end{array}$ & $\begin{array}{r}-1.722 \\
(1.497)\end{array}$ & $\begin{array}{c}0.036 \\
(0.104)\end{array}$ \\
\hline FDI lagged 3 & $\begin{array}{c}0.049 \\
(0.106)\end{array}$ & $\begin{array}{l}0.643 * * \\
(0.278)\end{array}$ & $\begin{array}{c}0.057 \\
(0.107)\end{array}$ \\
\hline $\begin{array}{l}\text { Log-likelihood } \\
\text { Restricted log-likelihood } \\
\text { Likelihood Ratio Test } \\
\text { Observations }\end{array}$ & $\begin{array}{r}-129.48 \\
-156.79 \\
54.62 \\
2392\end{array}$ & $\begin{array}{r}-42.69 \\
-64.75 \\
44.12 \\
2392\end{array}$ & $\begin{array}{r}-97.44 \\
-120.35 \\
45.82 \\
2392\end{array}$ \\
\hline
\end{tabular}

The coefficients are restricted to slopes equal zero, intercept equal to the mean of dependent variable, and $a$ and $b$ equal to one.

*** Asymptotic t-test significant at the $99 \%$ confidence level

* Asymptotic t-test significant at the $95 \%$ confidence level.

* Asymptotic t-test significant at the $90 \%$ confidence level. 
costs of familiarizing itself with U.S. protection laws, it is more likely to file future petitions for relief and obtain protection. However, contrary to hypothesis two, there is no significant relationship between lagged FDI and the threat of protection in these initial estimates.

To test whether the type of protection matters in finding a quid pro quo relationship in equation (2), we separately estimate the threat of EC protection and $\mathrm{AD}$ protection in columns 2 and 3 of table 2. As expected, the results are more encouraging. In particular, with respect to the threat of EC protection, FDI lagged one and two periods have the expected negative sign, though are statistically insignificant at the 90 percent confidence level. In contrast, lagged FDI is positively correlated with the threat of AD protection, and FDI lagged one period is statistically significant at the 90 percent confidence level. This suggests either quid pro quo FDI was unsuccessful in defusing an $\mathrm{AD}$ protectionist threat or there is anticipatory tariff-jumping in the face of an $\mathrm{AD}$ protectionist threat. This accords with hypothesis three that political appeasement is difficult with "technical track" AD investigations. Differences in the other regressors also show that the threat of EC protection is influenced by political factors more than the threat of $\mathrm{AD}$ protection is. In particular, the degree of union presence and the industry wage to value added, both signs of labor's political strength in an industry, are significantly correlated with the threat of EC protection, but not with the threat of $\mathrm{AD}$ protection. 
Table 3 explores how different forms of lagged FDI may affect the threat of EC protection.$^{24}$ Specifically, column 1 specifies lagged Japanese non-acquisition FDI, whereas column 2 lags Japanese acquisition FDI. Hypothesis 4 suggests that previous non-acquisition FDI should be more likely to defuse the threat of EC protection than acquisition FDI and the results show some support for this. The coefficients on nonacquisition FDI lagged one and two periods are larger and the one-period lag is significant at the 95 percent confidence level, suggesting stronger support for successful quid pro quo FDI with non-acquisition FDI than with all forms of FDI in general. In further support of hypothesis 4 , the coefficients on lagged acquisition FDI are statistically insignificant with respect to the threat of EC protection. The one inexplicable result is the strong positive correlation between non-acquisition FDI three period before and the threat of EC protection.

Before discussing estimation results for equation (4), it should be noted that a variety of specifications were tried for the dependent variable in equation (2). As noted earlier, our dependent variable takes the value of " 1 " when an investigation occurred that led to an affirmative ruling (i.e., led to protection). Specifying the binary variable as taking on the value of " 1 " when any investigation occurred (both ones that ended affirmative, as well as the negative cases) leads to similar, but slightly weaker results. This is logical in the sense that foreign firms may have information that negative cases

\footnotetext{
${ }^{24}$ For the sake of brevity, we do not show how different forms of lagged FDI affect AD protection. However, results show that lagged acquisition FDI has a particularly strong positive correlation with the threat of $\mathrm{AD}$ protection, whereas this is less of a case with non-acquisition FDI.
} 
Table 3

Probit Estimates for Predicting EC Affirmative Decisions on Japanese Products Across 4-Digit SIC Manufacturing Industries, 1980-1987.

\begin{tabular}{|c|c|c|}
\hline & $\begin{array}{l}\text { EC Threat of } \\
\text { Protection }\end{array}$ & $\begin{array}{c}\text { EC Threat of } \\
\text { Protection }\end{array}$ \\
\hline Constant & $\begin{array}{l}-5.014^{* * *} \\
(0.808)\end{array}$ & $\begin{array}{l}-4.452^{* * *} \\
(0.659)\end{array}$ \\
\hline Lagged real Japanese import growth & $\begin{array}{l}0.004^{*} \\
(0.003)\end{array}$ & $\begin{array}{l}0.004^{*} \\
(0.002)\end{array}$ \\
\hline Lagged real domestic shipments growth & $\begin{array}{r}-0.630 \\
(1.082)\end{array}$ & $\begin{array}{l}-0.628 \\
(1.001)\end{array}$ \\
\hline Share of Japanese imports to total Japanese imports & $\begin{array}{l}11.402^{* *} \\
(4.977)\end{array}$ & $\begin{array}{l}5.346 * * * \\
(1.984)\end{array}$ \\
\hline Share of Japanese imports to total all imports & $\begin{array}{c}-0.588 \\
(0.862)\end{array}$ & $\begin{array}{c}-0.185 \\
(0.735)\end{array}$ \\
\hline Union presence & $\begin{array}{l}0.018^{*} \\
(0.010)\end{array}$ & $\begin{array}{l}0.015^{*} \\
(0.009)\end{array}$ \\
\hline Industry wage to value added ratio & $\begin{array}{l}3.440^{* *} \\
(1.691)\end{array}$ & $(1.747 *)$ \\
\hline Past investigations of other countries' imports & $\begin{array}{c}0.517 \\
(0.398)\end{array}$ & $\begin{array}{c}0.559 \\
(0.368)\end{array}$ \\
\hline U.S. real GNP growth & $\begin{array}{l}0.139 * * \\
(0.068)\end{array}$ & $\begin{array}{c}0.097^{*} \\
(0.059)\end{array}$ \\
\hline Non-acquisition FDI lagged 1 & $\begin{array}{l}-1.123^{* *} \\
(0.567)\end{array}$ & \\
\hline Non-acquisition FDI lagged 2 & $\begin{array}{c}-2.000 \\
(1.568)\end{array}$ & \\
\hline Non-acquisition FDI lagged 3 & $\begin{array}{l}0.816 * * * \\
(0.307)\end{array}$ & \\
\hline Acquisition FDI lagged 1 & & $\begin{array}{c}-2.448 \\
(48.01)\end{array}$ \\
\hline Acquisition FDI lagged 2 & & $\begin{array}{l}-2.601 \\
(59.12)\end{array}$ \\
\hline Acquisition FDI lagged 3 & & $\begin{array}{c}-2.437 \\
(65.08)\end{array}$ \\
\hline $\begin{array}{l}\text { Log-dikejihood } \\
\text { Restricted log-likelihood' } \\
\text { Likelihood Ratio Test } \\
\text { Observations }\end{array}$ & $\begin{array}{r}-42.24 \\
-64.75 \\
45.02 \\
2392\end{array}$ & $\begin{array}{r}-47.11 \\
-64.75 \\
35.29 \\
2392\end{array}$ \\
\hline
\end{tabular}

The coefficients are restricted to slopes equal zero, intercept equal to the mean of dependent variable, and $a$ and $b$ equal to one.

***,**, and $*$ denote asymptotic $\mathrm{t}$-test significance as in table 2 . 
are less likely to lead to protection and thus economic behavior will change less than in a case that will lead to an affirmative decision. We also tried specifying 3 options (no investigation, investigation/negative decision, and investigation/affirmative decision) with multinomial logit and ordered logit and probit specifications. These specifications led to similar, but slightly weaker results. In addition, the various predicted probabilities generated by these models performed quite similar as regressors in testing of equation (4).

We next turn to estimation of equation (4), using predicted probabilities from the equation one as estimated in column 1 of table 2 . Column 1 of table 4 presents initial estimates of the Japanese FDI equation using a random effects negative binomial model. The equation shows excellent fit, as the likelihood ratio test easily rejects the null hypothesis that the slopes are equal to zero at a 99 percent confidence level. In addition, most of the traditional explanatory variables are of expected sign and consistent with other empirical studies of FDI. In particular, the effect of movements in the exchange rate and the theory of internalization (as proxied by R\&D expenditures) show strong support.

With respect to this paper's main focus, the predicted probability of protection is positively correlated with greater FDI activity in an industry at the 99 percent confidence level. Actual protection in place has the expected positive sign, but is statistically insignificant. At first glance this seems surprising. However, the majority of tariff-jumping may occur in only the first few years of new protection. If the effect of protection on FDI behavior diminishes substantially over time, the presence of 
Table 4

Random Effects Negative Binomial Estimates of Japanese FDI Across 4-Digit SIC Manufacturing Industries, 1981-1988

\begin{tabular}{|c|c|c|c|}
\hline & $\begin{array}{l}\text { All } \\
\text { FDI }\end{array}$ & $\begin{array}{l}\text { Acquisition } \\
\text { FDI }\end{array}$ & $\begin{array}{c}\text { Non-Acquisition } \\
\text { FDI }\end{array}$ \\
\hline Constant & $\begin{array}{l}2.395^{* * *} \\
(0.480)\end{array}$ & $\begin{array}{l}2.459^{*} \\
(1.435)\end{array}$ & $\begin{array}{l}1.783 * * * \\
(0.536)\end{array}$ \\
\hline Exchange rate & $\begin{array}{l}-0.014^{* * *} \\
(0.001)\end{array}$ & $\begin{array}{l}-0.014^{* * *} \\
(0.002)\end{array}$ & $\begin{array}{l}-0.014^{* * *} \\
(0.001)\end{array}$ \\
\hline R\&D expenditures & $\begin{array}{l}0.282^{* * *} \\
(0.063)\end{array}$ & $\begin{array}{l}0.255^{* * *} \\
(0.056)\end{array}$ & $\begin{array}{l}0.301^{* * *} \\
(0.063)\end{array}$ \\
\hline Keiretsu linkages & $\begin{array}{c}0.004 \\
(0.004)\end{array}$ & $\begin{array}{c}0.008 \\
(0.005)\end{array}$ & $\begin{array}{c}0.003 \\
(0.004)\end{array}$ \\
\hline Japanese real GNP growth & $\begin{array}{c}-0.017 \\
(0.045)\end{array}$ & $\begin{array}{c}0.013 \\
(0.075)\end{array}$ & $\begin{array}{c}-0.027 \\
(0.050)\end{array}$ \\
\hline Actual Protection & $\begin{array}{c}0.274 \\
(0.186)\end{array}$ & $\begin{array}{c}0.380 \\
(0.390)\end{array}$ & $\begin{array}{l}0.425^{* *} \\
(0.212)\end{array}$ \\
\hline Probability of Protection & $\begin{array}{l}5.384 * * * \\
(0.711)\end{array}$ & & \\
\hline Probability of EC protection & & $\begin{array}{c}0.189 \\
(4.064)\end{array}$ & $\begin{array}{l}5.541 * * * \\
(1.742)\end{array}$ \\
\hline Probability of AD protection & & $\begin{array}{r}7.584^{*} \\
(4.251)\end{array}$ & $\begin{array}{l}5.182^{* *} \\
(2.147)\end{array}$ \\
\hline $\mathbf{a}$ & $\begin{array}{l}6.288 * * * \\
(1.500)\end{array}$ & $\begin{array}{c}27.14 \\
(35.99)\end{array}$ & $\begin{array}{l}5.560^{* * *} \\
(1.427)\end{array}$ \\
\hline b & $\begin{array}{l}0.666^{* * *} \\
(0.092)\end{array}$ & $\begin{array}{c}0.631^{\star} \\
(0.164)\end{array}$ & $\begin{array}{l}0.682 * * * \\
(0,106)\end{array}$ \\
\hline $\begin{array}{l}\text { Log-likelihood } \\
\text { Restricted log-likelihood' } \\
\text { Likelihood Ratio Test } \\
\text { Observations }\end{array}$ & $\begin{array}{r}-1287.28 \\
-1617.43 \\
660.30 \\
2392\end{array}$ & $\begin{array}{r}-659.82 \\
-551.91 \\
215.82 \\
2392\end{array}$ & $\begin{array}{r}-1066.61 \\
-1412.66 \\
692.10 \\
2392\end{array}$ \\
\hline
\end{tabular}

The coefficients are restricted to slopes equal zero, intercept equal to the mean of dependent variable, and $a$ and $b$ equal to one.

*** Asymptotic t-test significant at the $99 \%$ confidence level.

** Asymptotic t-test significant at the $95 \%$ confidence level.

* Asymptotic t-test significant at the $90 \%$ confidence level. 
protection may not be significant in a data set with a time-series dimension, as used here. A second reason for insignificance may stem once again from pooling different forms of FDI together. Firms may engage in certain types of FDI in response to actual protection, just as we have hypothesized differences in FDI with respect to the threat of protection. Blonigen (1995), who found little relationship between protection and acquisition FDI, suggests that if protection tends to occur in industries where foreign firms have a competitive or technological advantage, they may be less inclined to acquire a firm in the host country than to set up their own operations. This suggests that foreign firms will use non-acquisition FDI to tariff-jump, not acquisition FDI.

Columns two and three of table 4 test the effect of different forms of FDI and different forms of protectionist threat on equation (4) results. The dependent variable is split into acquisition FDI and non-acquisition FDI, and the threat of protection variable is split into the threat of $\mathrm{AD}$ protection and the threat of $\mathrm{EC}$ protection. The results are generally consistent with the predictions of hypotheses 3 and 4 .

In column 3 there is a significant direct correlation between non-acquisition FDI and the threat of AD and EC protection. Acquisition FDI does not show a similar strong relationship with the threat of protection, particularly the threat of EC protection. This supports the notion that foreign firms do not use acquisition FDI to respond to protection that can be politically influenced. Interestingly, both forms of FDI respond strongly to the probability of AD protection. However, non-acquisition FDl responds in a stronger fashion to EC protection than AD protection, which is what hypothesis three predicts. Interestingly, the two sets of estimates show differential 
effects of actual protection on different forms of FDI. In support of Blonigen (1995), the two sets of estimates show that actual protection has statistically strong direct relationship with non-acquisition FDI, but not with acquisition FDI. In essence, there is little support that acquisition FDI is influenced by protection or the threat of protection.

\section{CONCLUSION}

This paper has confirmed that the threat of protection has a substantial impact on non-acquisition Japanese FDI in the United States in the 1980s. In addition, there is evidence that threat-responding FDI by the Japanese had political intentions of defusing the threat of protection as suggested by quid pro quo theory. This is seen in the type of FDI used to respond to protectionist threat and the type of protectionist threat which elicited a greater FDI response by the Japanese. The success of FDI in defusing the threat of protection is apparently determined by the type of FDI used and the type of protection targeted: non-acquisition FDI defuses EC protection.

But what are the relative impacts of actual protection and the threat of protection on non-acquisition FDI? In this nonlinear context, coefficient estimates are difficult to interpret. In addition, the protection variable is a dummy variable only taking on the values of zero or one. One to generate an estimate of these variables impacts is to simulate the impact of changes in the variables on the expected value of the dependent variable. In the case of the dummy variable, compare the mean at the two different values it may take. Fixing the other regressors at their means and use our 
estimated coefficients from column 3 of table 4 , in place protection means a 53 percent increase in the expected number of FDI occurrences in an industry for a given year. A similar simulation shows that if the threat of an EC affirmative decision rises from 5 percent to 10 percent, the expected number of FDI occurrences rises by approximately 32 percent. An identical simulation with respect to the threat of AD protection, increases expected FDI by approximately 30 percent. These simulations are sensitive to the value of the other regressors and starting points for the variable in question, but give some indication that the threat of protection rivals the effect of actual protection on FDI flows. 


\section{REFERENCES}

Azrak, Paul, and Kevin Wynne. 1995. "Protectionism and Japanese Direct Investment in the United States," Journal of Policy Modeling. 17(3): 293-305.

Baldwin, Robert E., and Jeffrey W. Steagall. 1994. "An Analysis of ITC Decisions in Antidumping, Countervailing Duty and Safeguard Cases," Weltwirtschaftliches Archiv. 130(2): 290-308.

Bayard, Thomas O., and Kimberly Ann Elliott. 1994. Reciprocity and Retaliation in U.S. Trade Policy. Washington, DC: Institute for International Economics.

Bhagwati, Jagdish N., Richard A. Brecher, Elias Dinopoulos, and T. N. Srinivasan. 1987. "Quid Pro Quo Foreign Investment and Welfare: A Political-EconomyTheoretic Model," Journal of Development Economics. 27: 127-38.

Bhagwati, Jagdish N., Elias Dinopoulos, and Kar-Yui Wong. 1992. "Quid Pro Quo Foreign Investment," American Economic Review. 82(2): 186-190.

Blonigen, Bruce A. 1995. Explaining Japanese Foreign Direct Investment in the United States. Ph.D. dissertation. University of California-Davis.

Caves, Richard E. 1989. "Exchange-Rate Movements and Foreign Direct Investment in the United States," in David B. Audretsch and Michael P. Claudon (Eds.), The Internationalization of U.S. Markets. N.Y.: N.Y. University Press.

Coughlin, Cletus C., Joseph V. Terza, and Noor Aini Khalifah. 1989. "The Determinants of Escape Clause Petitions," Review of Economics and Statistics, 71(2): 341-347.

Dinopoulos, Elias, 1992. "Quid Pro Quo Foreign Investment and VERs: A Nash Bargaining Approach," Economics and Politics. 4: 43-60.

Dinopoulos, Elias and Kar-Yiu Wong. 1991. "Quid Pro Quo Foreign Investment and Policy Intervention," in K. A. Koekkoek and C. B. M. Mennes, eds., International Trade and Global Development: Essays in Honour of Jagdish Bhagwati. London: Routledge. pp. 162-90.

Finger, J. M., H. Keith Hall, and Douglas R. Nelson. 1982. "The Political Economy of Administered Protection," American Economic Review. 72(3): 452-466.

Froot, Kenneth A. and Jeremy C. Stein. 1991. "Exchange Rates and Foreign Direct Investment: An Imperfect Capital Markets Approach," Quarterly Journal of Economics. 106(4): 1191-1217. 
Goldberger, Arthur S. 1972. "Maximum-Likelihood Estimation of Regressions Containing Unobservable Independent Variables," International Economic Review. 13(1): $1-15$.

Grossman, Gene, and Elhanan Helpman. 1994. "Foreign Investment with Endogenous Protection," NBER Working Paper, No. 4876.

Grubaugh, Stephen G. 1987. "Determinants of Direct Foreign Investment," Review of Economics and Statistics. 69(1): 149-152.

Hansen, Wendy L., and Thomas J. Prusa. Forthcoming, 1996. "Cumulation and ITC Decision-Making: The Sum of the Parts is Greater than the Whole," Economic Inquiry.

Hausman, Jerry, Bronwyn H. Hall and Zvi Griliches. 1984. "Econometric Models for Count Data with an Application to the Patents-R \& D Relationship," Econometrica. 52(4): 909-938.

Herander, M.G. and Schwartz, J.B. 1984. "An Empirical Test of the Impact of the Threat of U.S. Trade Policy: The Case of Antidumping Duties. Southern Economic Journal. 51(1): 59-79.

Kogut, Bruce and Sea Jin Chang. 1991. "Technological Capabilities and Japanese Foreign Direct Investment," Review of Economics and Statistics. 73(3): 401-413.

Lawrence, Robert Z. 1991. "Efficient or Exclusionist? The Import Behavior of Japanese Corporate Groups," Brookings Papers on Economic Activity. 1: 311-341.

Lawrence, Robert Z. 1993. "Japan's Low Levels of Inward Investment: The Role of Inhibitions on Acquisitions," in Kenneth Froot (Ed.), Foreign Direct Investment.

Chicago: University of Chicago Press (NBER).

Maddala, G.S. 1983. Limited-Dependent and Qualitative Variables in Econometrics. Cambridge: Cambridge University Press.

Martin, Stephen. 1991. "Direct Foreign Investment in the United States," Journal of Economic Behavior and Organization. 16: 283-293.

Moore, Michael. 1992. "Rules or Politics? An Empirical Analysis of ITC Antidumping Decisions," Economic Inquiry. 30: 449-466.

Pagan, Adrian. 1984. "Econometric Issues in the Analysis of Regressors With Generated Regressors," International Economic Review. 25(1): 221-247. 
Ray, Edward John. 1989. "The Determinants of Foreign Direct Investment in the United States, 1979-85, " in Robert C. Feenstra (Ed.), Trade Policies for International Competitiveness. Chicago: University of Chicago Press (NBER).

Salvatore, Dominick. 1987. "Import Penetration, Exchange Rates, and Protectionism in the United States," Journal of Policy Modeling. 9(1): 125-141.

Staiger, Robert and Frank Wolak. 1994. "Measuring Industry Specific Protection: Antidumping in the United States," NBER Working Paper No. 4696.

Swenson, Deborah L. 1994. "Impact of U.S. Tax Reform on Foreign Direct Investment in the United States," Journal of Public Economics. 54(2): 243-266.

Takacs, Wendy E. 1981. "Pressures for Protectionism: An Empirical Analysis," Economic Inquiry. 19: 687-693.

Trefler, Daniel. 1993. "Trade Liberalization and the Theory of Endogenous Protection: An Econometric Study of U.S. Import Policy," Journal of Political Economics.

101(1): 138-160. 


\section{DATA APPENDIX}

\section{Probability of Protection - Equation (2):}

1) Lagged real Japanese import growth

Data on Japanese imports at the 4-digit Standard Industrial Classification (SIC) level was obtained from a database maintained at the U.S. International Trade Commission (USITC) and based on official statistics of the U.S. Customs Service and concordances between Tariff Schedules of the United States Annotated (TSUSA) product codes and SIC categories. These figures were deflated using industry-specific price indexes taken from statistical tables in The Economic Report of the President, February, 1994, to get real levels. Finally, last period's growth rate over the previous period was calculated.

\section{2) Lagged domestic industry real shipments growth}

Data on U.S. domestic shipments by 4-digit SIC taken from the Census of

Manufactures, various issues. These figures were deflated using industry-specific price indexes taken from statistical tables in The Economic Report of the President, February, 1994, to get real levels. Finally, last period's growth rate over the previous period was calculated.

3) Share of Japanese industry's imports to total Japanese imports to U.S. Data on both Japanese imports and total annual Japanese imports to the United States at the 4-digit Standard Industrial Classification (SIC) level was obtained from a database maintained at the U.S. International Trade Commission (USITC) indicated above. Then for each industry $i$, this variable is defined as the ratio of Japanese imports in the industry $i$ in year $t$ to total Japanese imports to the United States in year $t$.

4) Share of Japanese industry's imports to industry imports from all countries Data on both Japanese imports and total imports by industry to the United States at the 4-digit Standard Industrial Classification (SIC) level was obtained from a database maintained at the U.S. International Trade Commission (USITC) indicated above. Then for each industry $i$, this variable is defined as the ratio of Japanese imports in the industry $i$ in year $t$ to all imports to the United States in industry $i$ in year $t$.

\section{5) Union presence}

Taken from Freeman, Richard B. and James L. Medoff. (1979). "New Estimates of Private Sector Unionism in the United States," Industrial and Labor Relations Review. 32(2): 143-174. Estimates were for 3-digit SIC level, and thus repeated at 4-digit level for this study. Variable is defined as percent of union membership of all workers in column 3 of table 2, beginning on page 155.

6) Industry wage to value added ratio Census of Manufactures, various issues. 
7) Investigations in industry of other countries in previous two years USITC publications, The Year in Trade and Annual Report of the USITC, various issues. Variable is defined as " 1 " if AD or CVD petition is filed on other countries' products in industry $\mathrm{i}$ in previous two years.

\section{8) U.S. real GNP growth}

Taken from statistical tables in The Economic Report of the President, February, 1994.

\section{9) Lagged FDI}

Same source as used for the dependent variable in equation (2') discussed in text.

\section{Foreign Direct Investment - Equation (4):}

\section{1) R\&D Expenditures}

This variable is defined as company and other (except Federal) R\&D funds as a percent of net sales in R\&D-performing manufacturing companies, by industry, taken from the National Science Foundation's publication, Selected Data on Research and Development in Industry: 1991, p 18. The majority of these figures were reported at the 2-digit SIC level and then applied to my 4-digit SIC level data. Some of the more important industries, including chemical (SIC 28), primary metals (SIC 33), industrial machinery (SIC 35), electrical machinery (SIC 36), transportation (SIC 37), and instruments (SIC 38), were detailed at the 3-digit SIC level by the NSF figures.

2) Yen-dollar exchange rate

Taken from statistical tables in The Economic Report of the President, February, 1994.

\section{3) Japanese real GNP growth}

Taken from the Japan Statistical Yearbook, Japan Statistics Bureau, Management and Coordination Agency.

\section{3) Keiretsu linkages}

Calculated in similar manner to that used by Lawrence (1993). The publication Industrial Groupings in Japan, 1988/89, published by Dodwell Marketing Consultants, lists major firms, their revenues, and their keiretsu linkages by industry. The keiretsu linkage variable was constructed by calculating the percentage of revenues in each industry that were attributable to a firm with keiretsu affiliation.

\section{4) Actual protection}

USITC publications, The Year in Trade and Annual Report of the USITC, various issues. Variable is defined as a " 1 " if AD duties or VER are in place for an industry $i$ in year $\mathrm{t}$; " 0 " otherwise. 